NBER WORKING PAPER SERIES

\title{
MONOPSONY POWER IN HIGHER EDUCATION: A TALE OF TWO TRACKS
}

\author{
Austan Goolsbee \\ Chad Syverson \\ Working Paper 26070 \\ http://www.nber.org/papers/w26070 \\ NATIONAL BUREAU OF ECONOMIC RESEARCH \\ 1050 Massachusetts Avenue \\ Cambridge, MA 02138 \\ July 2019
}

We would like to thank Pengyu Ren for his outstanding research assistance and David Deming, Emir Kamenica, Pete Klenow, Neale Mahoney, Magne Mogstad, Suresh Naidu, Canice Prendergast, Robert Topel, Seth Zimmerman and seminar participants at the University of Chicago for helpful comments. We thank the Initiative on Global Markets at the University of Chicago's Booth School for financial assistance. The views expressed herein are those of the authors and do not necessarily reflect the views of the National Bureau of Economic Research.

At least one co-author has disclosed a financial relationship of potential relevance for this research. Further information is available online at http://www.nber.org/papers/w26070.ack

NBER working papers are circulated for discussion and comment purposes. They have not been peer-reviewed or been subject to the review by the NBER Board of Directors that accompanies official NBER publications.

(C) 2019 by Austan Goolsbee and Chad Syverson. All rights reserved. Short sections of text, not to exceed two paragraphs, may be quoted without explicit permission provided that full credit, including $(\odot$ notice, is given to the source. 
Monopsony Power in Higher Education: A Tale of Two Tracks

Austan Goolsbee and Chad Syverson

NBER Working Paper No. 26070

July 2019

JEL No. I23,J42

\begin{abstract}
$\underline{\text { ABSTRACT }}$
This paper tests for and measures monopsony power in the U.S. higher education labor market. It does so by directly estimating the residual labor supply curves facing individual four-year colleges and universities using school-specific labor demand instruments. The results indicate that schools have significant monopsony power over their tenure track faculty. Its magnitude is monotonic in rank, being greatest over full professors and smaller for associate and assistant professors. For non-tenure track faculty, however, universities do not seem to have any monopsony power and instead face perfectly elastic residual labor supply curves. Universities' market power over tenure track faculty does not differ between public and private schools nor between female and male faculty. Monopsony power is greater for larger universities, and the geographic market for faculty seems to be national rather than local. Monopsony power is also larger at higher-status institutions as measured by Carnegie classifications, average test scores of the undergraduate student body, or initial salary rankings. The results also suggest that monopsony power has contributed to the trend toward non-tenure track faculty in U.S.
\end{abstract}

\author{
Austan Goolsbee \\ Booth School of Business \\ University of Chicago \\ 5807 S. Woodlawn Avenue \\ Chicago, IL 60637 \\ and NBER \\ goolsbee@chicagobooth.edu \\ Chad Syverson \\ University of Chicago \\ Booth School of Business \\ 5807 S. Woodlawn Ave. \\ Chicago, IL 60637 \\ and NBER \\ chad.syverson@chicagobooth.edu
}




\section{Introduction}

Rising income inequality and the decline in labor's share of income in the United States, coupled with a rise in ownership concentration in most industries, have put the issue of monopsony power and the lack of bargaining power of workers back in the spotlight for policy makers, economic researchers, and even in the popular press. ${ }^{1}$

The economics literature has tried to document the existence of monopsony power in a variety of settings and with a variety of approaches. These have often relied on more indirect methods than estimating the residual supply curve facing an individual firm. ${ }^{2}$ This is because the data needed to identify classical monopsony power includes firm-level labor demand shifters that are not easy to find. ${ }^{3}$

In this paper, we directly estimate firm-level labor supply curves to test for monopsony power in the college and university labor market. Our methodology uses school-level instruments for labor demand derived from lagged application patterns at that school to identify the residual labor supply. ${ }^{4}$

\footnotetext{
${ }^{1}$ See the discussions in Council of Economic Advisers (2016), U.S. Department of Treasury (2016), Autor et al. (2017).

2 Boal and Ransom (1997) and Ashenfelter et al. (2010) survey some of the classical monopsony literature. Types of tests for monopsony include those relating labor market outcomes to employer concentration like Abel et al. (2018), Azar et al. (2017, 2019), Benmelech et al. (2018), and Prager and Schmitt (2019); exploring pass-through of rents to workers as in Kline et al. (2017) or Lamadon et al. (2019); comparing wages to workers' estimated marginal revenue products like Isen (2013), Scully (1974), Somppi (1985), and Zimbalist (1992); and looking at the employment effects of minimum wage and labor market policies as in Card and Krueger (1995, 2000), Dube et al. (2007), Manning (1996), and Naidu et al. (2016). A somewhat distinct form and style of modelling monopsony comes out of search-theoretic models of the labor market and uses data on labor flows. This "dynamic monopsony" approach is explored extensively in Bhaskar et al. (2002) and Manning (2003), and surveyed in Manning (2011). ${ }^{3}$ Some prominent exceptions that have directly estimated firm level labor supply curves include the work of Hirsch and Schumacher (1995), Matsudaira (2014), Staiger et al. (2010), and Sullivan (1989) on nurses, Falch (2010) on teachers, and Boal (1995) on coal miners. Most of these studies take the form of evaluating a natural experiment in the form of a wage change from a specific one-time policy change with differential impacts on wages across firms. Interesting direct experimental evidence where researchers vary the wage and estimate the residual labor supply elasticity includes Dal Bo et al. (2013) and Dube et al (forthcoming). ${ }^{4}$ We use "school," "college," "university," and "institution" interchangeably in the paper.
} 
The existence of monopsony power in the higher education industry has been the subject of intense debate in previous years, but this debate has relied on indirect or suggestive methods like comparing seniority wage premia in higher education to other industries. ${ }^{5}$

The results indicate that schools do have significant monopsony power over their tenure track faculty (that is, the tenure track labor supply curve to the school is not flat), and that market power is highest for full professors and smaller farther down the academic ladder. Interestingly, on the other hand, schools are wage-takers for non-tenure track faculty. There is no significant evidence of monopsony power over that group.

There are interesting dimensions of variation in this monopsony power. Private and public institutions have similar monopsony power, and the labor supply elasticities facing schools do not seem to differ between male and female faculty. However, the average degree of monopsony power is rising over our sample and does not appear to be a short-run phenomenon for individual universities. Furthermore, schools with higher levels of prestige as measured by Carnegie classifications or average student test scores have significantly higher monopsony power over their tenure track faculty. Larger schools do as well.

Section II will discuss the monopsony literature and the classical monopsony model we estimate. Section III overviews the higher education market and the data. Section IV presents the basic results documenting monopsony in academic labor markets and how it has changed over time. Section V examines the heterogeneity across schools in their monopsony power. Section VI explores the rise of non-tenure track faculty in the last 15 years and whether monopsony helps explain it. Section VII concludes.

\section{Monopsony in Higher Education and How to Detect It}

\footnotetext{
${ }^{5}$ See, for example, Ransom (1993), Hallock (1995), Monks and Robinson (2001).
} 
Colleges and universities provide an interesting test case for labor market monopsony. The data allow us to examine the existence of monopsony but it remains policy-relevant in its own right. The Department of Justice has recently argued that university conduct relating to faculty hiring can be considered anti-competitive antitrust violations (U.S. Department of Justice, 2019).

There are several elements suggestive of employer market power at colleges and universities. First, the popular and trade press have argued vociferously and at length that schools have exploited their faculty, especially adjunct and contingent faculty, with very low wages and poor working conditions. ${ }^{6}$

Second, in the economic sense, schools are definitely not homogeneous employers in terms of geography, size, prestige, and other dimensions. There also seem to be significant switching costs for faculty that rise with tenure at the school. By turning schools into "differentiated products," these factors raise the prospect of employer market power.

Rather than rely on indirect methods, our basic test of monopsony power centers on estimating the residual labor supply curve facing each institution. A firm with monopsony power is not a wage-taker and can cut wages below competitive levels without losing all its workers. Hiring workers drives up wages for infra-marginal workers. This basic idea suggests a straightforward way to measure of monopsony (provided we can obtain sufficient data) is to estimate the inverse labor supply curve facing the individual institution:

$$
\ln \left(W_{i t}\right)=\mu \ln \left(L_{i t}\right)+\text { School }_{i}+\text { Year }_{t}+\epsilon_{i t}
$$

where $W_{i t}$ is the wage paid by employer (here, college or university) $i$ in period (year) $t$, and $L_{i t}$ is the amount of labor (number of faculty) $i$ employs in $t$. The specification also includes school and year fixed effects. The coefficient $\mu$ is the

6 See, for example, O’Shaughnessy (2012), Hoeller (2014), Fredrickson (2015), Bodenheimer (2018), Childress (2019), and Chronicle of Higher Education (2019). 
inverse of the labor supply elasticity facing the individual school. In a competitive labor market, $\mu=0$ (firm level labor supply is infinite), and the firm can hire or fire without changing the wage it pays. If $\mu>0$, then the firm faces an upward sloping residual labor supply. This creates an incentive to reduce employment relative to the competitive market and put a wedge between the marginal product of labor and the wage. For a cost-minimizing firm in the standard model, $\mu$ should be the size of this wedge, analogous to the Lerner index in the product market monopoly context.

The basic problem with estimating equation (1) has always come from the data. First, it requires institution level wage and quantity data. Two, it requires firm-level instruments for labor demand to get around the standard identification problem. (This is the factor market analog to using firm-level cost shifters to estimate residual demand curves in an industry, as described in Baker and Bresnahan, 1988.) Fortunately, there is institution-level data on wages and faculty employment as well as labor-demand shifting instruments.

\section{Data}

Our primary data come from the Integrated Postsecondary Education Data System (IPEDS) of the Department of Education's National Center for Education Statistics. All schools eligible for financial aid under Title IV of the Higher Education Act of 1965 (e.g., Pell Grants, Stafford Loans) must provide detailed statistical information annually on their students, faculty, employees, and institutions. It amounts to something like a census of colleges and universities and, being mandatory, has a compliance rate of close to $100 \%$ of institutions (though some individual data elements are missing). ${ }^{7}$

We take the information from the Human Resources component of IPEDS on the number of full-time instructional faculty of various ranks and their

\footnotetext{
${ }^{7}$ More details on the IPEDS data methodology can be found in Ginder et al. (2018) or at the online guide to the IPEDS survey components (https://nces.ed.gov/ipeds/use-thedata/survey-components).
} 
average wage. In some specifications, we will use the information broken out by gender, institution type, the school's student characteristics, and so on.

Schools differ in their classifications of what they call a tenured rank (just full professors, for example, versus associate professors). They also differ somewhat over what constitutes the tenure track and what they term the adjunct faculty (e.g., instructors, lecturers, non-ranked faculty). When we refer to 'tenure track' faculty, we include the three categories of instructional faculty in IPEDS: full professors, associate professors, and assistant professors. When we refer to 'non-tenure track' or 'adjunct' faculty, we include instructors, lecturers, and non-ranked faculty.

Importantly, we will only be looking at full-time faculty. IPEDS data include information on part time faculty headcounts, but their average salary varies over time with both their hours (unobservable to us) and their wages. Therefore we cannot estimate a residual supply curve for them. This is of greatest concern regarding our non-tenure track faculty estimates, as the majority of them are part-time, but we can only estimate a residual supply curves for the full-time adjunct faculty. Implicitly, we are assuming that demand and wages for the full-time and part time faculty behave in similar ways.

Based on the data, however, this assumption might be reasonable. While IPEDS lacks data on hours worked, it does give the headcount ratio of full-topart-time adjunct faculty and that has remained rather constant over the sample. This is shown in Figure 1, which presents the time dummies from a regression of the share of colleges' full-time adjunct faculty among all adjunct faculty on school and time fixed effects. We will see later that the share of all faculty that are non-tenure track has risen dramatically, but the result here shows that the full-to-part-time ratio of non-tenure track faculty has remained stable, bolstering our assumption of symmetric patterns between them. 
IPEDS also includes information about enrollments and applications at the school. We use these when designing our instrument for school-specific labor demand, as described further below.

We examine four year, not-for-profit colleges and universities in the 50 U.S. states plus D.C. (i.e., we exclude two year schools, for-profit schools, schools in U.S. territories, etc.). Given our reliance on applications data as a demand instrument, we also drop schools with open enrollment, because they do not report data on the number of applications they receive. The applications data starts in the 2001-2002 academic year, so our sample spans the 14-year period from 2002-2003 to 2016-2017. We end up with around 1650 institutions in our sample with enough information to be included in at least one of our empirical specifications.

\section{Basic Results \\ a. OLS}

We start by looking at the reduced form relationship of the log of the average monthly wage on the logged quantity of labor. The results are in Table 1.

Table 1. Estimating Inverse Labor Supply without Instruments: OLS

\begin{tabular}{ccc} 
Dep Variable: $\ln \left(\mathrm{W}_{\mathrm{it}}\right)$ & Non-Tenure Track & Tenure Track \\
\hline $\ln \left(\mathrm{L}_{\mathrm{it}}\right)$ & -0.0123 & -0.0042 \\
& $0.0078)$ & $(0.0193)$ \\
\hline Observations & 19,944 & 21,162 \\
$R^{2}$ & 0.850 & 0.969 \\
Adjusted $R^{2}$ & 0.837 & 0.966 \\
Year FE & Yes & Yes \\
Institution FE & Yes & Yes
\end{tabular}

Notes: The data are taken from IPEDS with the definitions given in the paper. The sample spans the 2002-03 to 2016-17 academic years. Each regression looks at labor supply of the group listed at the top of the column. Standard errors are shown in the parentheses and clustered at the school level. The regressions are weighted by the total faculty head count for the school across the full sample. 
Each regression includes school and year fixed effects, and observations are weighted by the school's total faculty headcount over the full sample. We cluster standard errors by school. Column (1) shows the relationship for nontenure track faculty and column (2) for tenure track faculty.

In both cases, the coefficient is close to and not significantly different from zero. Given the inverse elasticity form, if these were the school-level supply curves, they would suggest residual supply elasticities that are infinite. In other words, they would imply that schools are wage takers when hiring faculty.

\section{b. Instrumenting for Institution-Level Labor Demand}

The issue, of course, is that the OLS regression is not a supply curve because both supply and demand may be moving simultaneously. If outward shifts in labor supply tend to reduce wages, or the reverse, this will impart a negative bias on the estimates of $\mu$ in (1).

To identify the residual labor supply elasticity facing a single school, we need an instrument for labor demand at that individual school. Such an instrument would allow us to use only the variation in wages that is orthogonal to labor supply shocks to identify the slope of the labor supply curve.

Labor demand, like any factor demand, is derived from the demand for firms' final products. Therefore a college's labor demand curve is shifted by changes in students' demand for education at that school. Student enrollments obviously reflect student demand, but they may not be a suitable instrument because enrollment also depends on schools' admission decisions, which could in turn be shaped by shifts in faculty labor supply. This would violate the exclusion condition.

Instead, we use a direct measure of student demand: the number of undergraduate applications. Variations in applications reflect differences in students' desires to attend particular universities whether in the cross section 
or over time, but are not dependent on any choice of the university itself. The number of applicants is influenced by things like demographics, the availability of foreign student visas, local and national economic prospects for potential students, and so on. Our instrument uses undergraduate applications rather than total applications because the former are more consistently reported across schools in the sample. However, using total applications for the schools where we observed them did not make a noticeable difference in the results. Because admitted applicants do not show up as actual students until at least one academic year after their application, we use lagged (logged) applications for our instrument. Lagged applications are strongly correlated with followingyear enrollments in our data. ${ }^{8}$

Table 2 shows the results of the first stage regression separately for both non-tenure track and tenure track faculty, as well as broken out by tenure track faculty ranks. In each case, the lagged applications strongly predicts the quantity of both tenure track and non-tenure track faculty in the following year. The F-statistics for instrument relevance are well above values that might indicate weak-instrument concerns.

Table 2. Faculty Headcounts Inverse Elasticity First Stage Regression

\begin{tabular}{ccc||ccc}
\hline \multirow{2}{*}{ Dep Variable: $\ln \left(\mathrm{L}_{\mathrm{it}}\right)$} & $\begin{array}{c}(1) \\
\text { Non-Tenure } \\
\text { Track }\end{array}$ & $\begin{array}{c}\text { Tenure } \\
\text { Track }\end{array}$ & $\begin{array}{c}(3) \\
\text { Professor }\end{array}$ & $\begin{array}{c}(4) \\
\text { Associate } \\
\text { Prof. }\end{array}$ & $\begin{array}{c}\text { Assistant } \\
\text { Prof. }\end{array}$ \\
\hline $\ln$ (Applications it-1 $)$ & 0.2379 & 0.0847 & 0.0469 & 0.0701 & 0.1226 \\
& $(0.0417)$ & $(0.0150)$ & $(0.0117)$ & $(0.0126)$ & $(0.0245)$ \\
\hline Observations & 19,944 & 21,162 & 20,969 & 20,698 & 20,623 \\
$R^{2}$ & 0.918 & 0.991 & 0.989 & 0.981 & 0.958 \\
Adjusted $R^{2}$ & 0.911 & 0.990 & 0.988 & 0.979 & 0.955 \\
First stage F Stat & 32.5 & 32.1 & 16.1 & 31.0 & 25.0 \\
Year FE & Yes & Yes & Yes & Yes & Yes \\
Institution FE & Yes & Yes & Yes & Yes & Yes \\
\hline
\end{tabular}

Notes: The data are taken from IPEDS with the definitions given in the paper. The sample spans the 2002-03 to 2016-17 academic years. Each regression looks at labor supply of the group listed at the top of the column. Standard errors are shown in the parentheses and clustered at the school level. The regressions are weighted by the total faculty head count for the school across the full sample.

${ }^{8}$ There has been a secular increase in the number of applications per student. Total applications per school over the 14 years in our sample rose about $75 \%$ while total enrollment rose about $20 \%$. 
While we of course cannot directly test the exclusion condition, it is worth noting that any unobservables that make a school desirable for both students and faculty (in other words, result in labor supply shifts that are positively correlated with changes in student demand, and therefore labor demand) will tend to reduce the equilibrium wage as demand rises, biasing the results toward finding no monopsony power. Only labor supply shifts that are negatively correlated with student applications would cause our specification to indicate more monopsony than actually exists. We did investigate the possibility that periods of high enrollment raise the reservation wage for faculty by raising their workload. However, we found no relationship between enrollments or applications and the schools' student-teacher ratios. Further, as we will see, any problematic correlated inward supply shifts would need to exist for tenure track faculty but not non-tenure track faculty, and be larger for full professors than associate professors, and larger in turn for associate professors than assistant professors.

\section{c. Instrumental Variable Estimates of Monopsony Power}

With this school-specific labor demand shifter as our instrument, we can estimate schools' residual labor supply curves using two-stage least squares. We present these results in Table 3. Columns (1) and (2) show the results for the non-tenure track and the tenure track faculty. Columns (3)-(5) then do the regression separately within the tenure track category for each academic rank.

The labor supply elasticity is the inverse of the coefficient. Column (1)'s coefficient is small and not significantly different from zero, suggesting that the schools are wage-takers for non-tenure track faculty. Column (2), however, indicates the presence of significant market power in the market for tenure track faculty at the school level. An idiosyncratic increase in demand for labor at a specific school significantly drives up the wages at that school. The school- 
specific labor supply elasticity for tenure track faculty in this specification is around 5.9

Table 3. Inverse Elasticity of Labor Supply: IV

\begin{tabular}{|c|c|c|c|c|c|}
\hline Dep Variable: $\ln \left(\mathrm{W}_{\mathrm{it}}\right)$ & $\begin{array}{c}(1) \\
\text { Non-Tenure } \\
\text { Track }\end{array}$ & $\begin{array}{c}\text { (2) } \\
\text { Tenure } \\
\text { Track }\end{array}$ & $\begin{array}{c}\text { (3) } \\
\text { Professor }\end{array}$ & $\begin{array}{c}(4) \\
\text { Associate }\end{array}$ & $\begin{array}{c}(5) \\
\text { Assistant }\end{array}$ \\
\hline $\ln \left(\mathrm{L}_{\mathrm{it}}\right)$ & $\begin{array}{c}0.0348 \\
(0.0320)\end{array}$ & $\begin{array}{c}0.1957 \\
(0.0809)\end{array}$ & $\begin{array}{c}0.5361 \\
(0.1542)\end{array}$ & $\begin{array}{c}0.3258 \\
(0.0754)\end{array}$ & $\begin{array}{c}0.1277 \\
(0.0661)\end{array}$ \\
\hline $\begin{array}{l}\text { Observations } \\
\text { Year FE }\end{array}$ & $\begin{array}{c}19,944 \\
\text { Yes }\end{array}$ & $\begin{array}{c}21,162 \\
\text { Yes }\end{array}$ & $\begin{array}{c}20,969 \\
\text { Yes }\end{array}$ & $\begin{array}{l}20,698 \\
\text { Yes }\end{array}$ & $\begin{array}{l}20,623 \\
\text { Yes }\end{array}$ \\
\hline Institution $\mathrm{FE}$ & Yes & Yes & Yes & Yes & Yes \\
\hline $\begin{array}{c}\text { Instrument } \\
\text { First stage F Stat }\end{array}$ & $\begin{array}{l}\ln \left(\mathrm{Apps}_{\mathrm{it}-1}\right) \\
32.5\end{array}$ & $\begin{array}{c}\ln \left(\mathrm{Apps}_{\mathrm{it}-1}\right) \\
32.1\end{array}$ & $\begin{array}{l}\ln \left(\operatorname{Apps}_{\mathrm{it}-1}\right) \\
16.1\end{array}$ & $\begin{array}{l}\ln \left(\mathrm{Apps}_{\mathrm{it}-1}\right) \\
31.0\end{array}$ & $\begin{array}{c}\ln \left(\mathrm{Apps}_{\mathrm{it}-1}\right) \\
25.0\end{array}$ \\
\hline
\end{tabular}

The results breaking out the tenure track results separately by rank in columns (3)-(5) indicate monopsony power in all three cases. Monopsony power is monotonic in rank, being the largest for full professors, smaller for associate professors, and smaller still (and only marginally statistically significant, $\mathrm{p}=$ 0.053) for assistant professors. The implied residual labor supply elasticities are around 1.9 for full professors, 3.1 for associate professors, and 7.8 for assistant professors. These rank-specific results are consistent with tenure track faculty's willingness or ability to switch to another employer falling with rank, a result we find intuitive. We explore the implications of such product differentiation more below.

\section{Additional Results \\ a. Wage Discrimination/Differences}

\footnotetext{
${ }^{9}$ Note, this is not direct evidence that schools optimally exploit their market power when setting wages. This evidence documents only the existence of market power and, thus, the potential for a school to set wages below marginal product for tenure track faculty by the costminimizing amount. The actual degree to which schools exploit their market power depends on their conduct.
} 
The two key elements of the classic monopsony model are that firms face upward sloping residual labor supply and that they cannot price discriminate between workers. If schools could price discriminate, they would not face pressure to raise wages of existing faculty when hiring new faculty.

One of the drawbacks of the IPEDS data for our purpose is that we only observe average wages for an entire group. We do not have different wages for different fields of study, for example, nor for different people at each rank. Thus we cannot directly detect if universities pay new faculty higher wages while holding existing faculty wages fixed. Of course, to the extent such ability exists, it would reduce the effect of hiring on wages and bias us away from a finding of monopsony power. Nevertheless, we indirectly explore this possibility in two ways.

One, most public schools make faculty salary information public. The institutional pressures for equality within ranks or to raise existing faculty wages if new faculty wages rise should be stronger. We compare the estimated monopsony power for public and private schools in Table 4 by including the main effect and then an interaction with a dummy equal to one for public schools. The results show both public and private schools face perfectly elastic supply of non-tenure track faculty (column 1) and have monopsony power over tenure track faculty (column 2). Neither regression indicates a statistically significant difference in estimated elasticities across public and private schools.

Two, we can look at whether the estimated degree of monopsony power seems to depend on the size of the flow of new faculty. If our coefficient is just picking up price discrimination between new versus old faculty, say, the effect of hiring on average wages should be larger the greater is the net hiring rate of new faculty as a share of total faculty. In other words, if average wage changes actually only reflect wages of marginal workers, the greater are the share of marginal workers, the larger the estimated wage effect should be. Columns (3) and (4) interact the labor quantity with the hiring rate of new faculty in the 
year as a share of the existing stock of faculty. (We measure the stock as the average of the prior and current year's faculty headcount in order to reduce the influence of episodes where the prior base is small and hiring rates would tend toward infinity.) Column (3) continues to show there is not monopsony power for non-tenure track faculty while column (4) shows that there is for the tenure track. The coefficients on the interaction terms, though, are insignificant. The relative amount of marginal tenure track hiring is not statistically related to the increase in average faculty wages.

Table 4. Inverse Elasticity of Labor Supply: Wage Differentiation, Results by Gender

\begin{tabular}{|c|c|c|c|c|c|c|}
\hline & (1) & (2) & (3) & (4) & (5) & (6) \\
\hline Dep Variable: $\ln \left(\mathrm{W}_{\mathrm{it}}\right)$ & $\begin{array}{l}\text { Non- } \\
\text { Tenure } \\
\text { Track }\end{array}$ & $\begin{array}{c}\text { Tenure } \\
\text { Track }\end{array}$ & $\begin{array}{c}\text { Non- } \\
\text { Tenure } \\
\text { Track }\end{array}$ & $\begin{array}{l}\text { Tenure } \\
\text { Track }\end{array}$ & $\begin{array}{l}\text { Non- } \\
\text { Tenure } \\
\text { Track }\end{array}$ & $\begin{array}{l}\text { Tenure } \\
\text { Track }\end{array}$ \\
\hline $\ln \left(L_{\mathrm{it}}\right)$ & $\begin{array}{c}0.0513 \\
(0.0402)\end{array}$ & $\begin{array}{c}0.2183 \\
(0.0881)\end{array}$ & $\begin{array}{c}0.0213 \\
(0.0381)\end{array}$ & $\begin{array}{c}0.1469 \\
(0.0520)\end{array}$ & $\begin{array}{c}0.0231 \\
(0.0312)\end{array}$ & $\begin{array}{c}0.1814 \\
(0.0844)\end{array}$ \\
\hline $\ln \left(L_{i t}\right) \times$ Public & $\begin{array}{l}-0.0395 \\
(0.0293)\end{array}$ & $\begin{array}{l}-0.0893 \\
(0.0641)\end{array}$ & & & & \\
\hline $\ln \left(L_{i t}\right) \times$ Flow Rate $e_{i t}$ & & & $\begin{array}{c}0.0009 \\
(0.0025)\end{array}$ & $\begin{array}{c}0.0121 \\
(0.0108)\end{array}$ & & \\
\hline Flow Rate ${ }_{i t}$ & & & $\begin{array}{l}-0.0052 \\
(0.0119)\end{array}$ & $\begin{array}{l}-0.1197 \\
(0.0456)\end{array}$ & & \\
\hline $\ln \left(L_{i t}\right) \times$ Male & & & & & $\begin{array}{c}0.0222 \\
(0.0028)\end{array}$ & $\begin{array}{c}0.0075 \\
(0.0079)\end{array}$ \\
\hline Observations & 19,944 & 21,162 & 19,281 & 18,254 & 37,208 & 41,954 \\
\hline Year FE & Yes & Yes & Yes & Yes & Yes & Yes \\
\hline Institution $\mathrm{FE}$ & Yes & Yes & Yes & Yes & Yes & Yes \\
\hline Academic Rank & NT & TT & NT & TT & NT & TT \\
\hline First stage F Stat & 17.5 & 16.2 & 18.7 & 9.0 & 16.4 & 15.2 \\
\hline
\end{tabular}

Notes: The data are taken from IPEDS with the definitions given in the paper. The sample spans the 2002-03 to 2016-17 academic years. Each regression looks at labor supply of the group listed at the top of the column. Standard errors are shown in the parentheses and clustered at the school level. The regressions are weighted by the total faculty head count for the school across the full sample. The instrument is the lagged level of $\ln$ (Applications) as described in the text. 'Public' indicates a dummy variable for public institutions. 'Flow Rate' measure the net hiring rate as a share of the average faculty stock from the preceding two years. Column (5) and (6) combine for men and women for the same institution (hence the doubling of the number of observations) and include a dummy variable for men.

Finally, we note that some universities have formal policies to implement inframarginal wage increases when hiring new faculty. Such "no inversion" rules require that current faculty, or at least some defined subset of current 
faculty, are not paid less than recent hires. More formal institutional policies such as this may also be associated with less codified yet nonetheless influential attitudes that tend to build inframarginal wage growth into hiring.

\section{b. Gender}

One issue that arises in existing the existing monopsony literature (and that was first raised in the original discussion of monopsony in Robinson, 1969 ) is the tie to gender. Arguments about whether women have larger adjustment costs or put a higher value on flexible work arrangements, and whether such factors might give employers more monopsony power, arise in studies like Barth and Dale-Olsen (2009), Hirsch et al. (2010), Ransom and Oaxaca (2010), and Mas and Pallais (2017). Several other papers have examined gender differences and discrimination in academic labor markets specifically. ${ }^{10}$

Because the IPEDS data report average salary and headcount information separately for men and for women, we can repeat our basic results and test for different monopsony power by gender. We do this in columns (5) and (6) by interacting the main effect with gender. We find no significant difference in the school-specific labor supply elasticities of men and women tenure track faculty. The inverse labor supply of male non-tenure track faculty is significantly different from that of female non-tenure track faculty, but neither is significantly different from zero.

\section{c. Monopsony Power Over Time}

We next consider the evidence regarding the evolution of monopsony power over time. First, in Table 5, columns (1) and (2) interact labor quantity with a linear time trend. Again we find evidence of market power over tenure track faculty but not for adjunct faculty. For the tenure track faculty, though, market

10 See, for example, Hoffman (1976), Ginther and Hayes (1999) or Monks and Robinson (2000). 
power has increased at a small but significant rate over the 14-year sample. The implied drop in the school-level labor supply elasticity is from 5.6 to 4.6.

Table 5. Inverse Elasticity of Labor Supply: Market Power over Time

\begin{tabular}{|c|c|c|c|c|}
\hline Dep Variable: Varies & $\begin{array}{l}(1) \\
\text { Non- } \\
\text { Tenure } \\
\text { Track }\end{array}$ & $\begin{array}{l}(2) \\
\text { Tenure } \\
\text { Track }\end{array}$ & $\begin{array}{l}(3) \\
\text { Non- } \\
\text { Tenure } \\
\text { Track }\end{array}$ & $\begin{array}{l}(4) \\
\text { Tenure } \\
\text { Track }\end{array}$ \\
\hline $\ln \left(\mathrm{L}_{\mathrm{it}}\right)$ & $\begin{array}{l}0.0269 \\
(0.0352)\end{array}$ & $\begin{array}{l}0.1691 \\
(0.0787)\end{array}$ & & \\
\hline $\ln \left(L_{i t}\right) \times$ Time & $\begin{array}{l}0.0010 \\
(0.0008)\end{array}$ & $\begin{array}{l}0.0029 \\
(0.0004)\end{array}$ & & \\
\hline $\ln \left(\mathrm{L}_{17}\right)-\ln \left(\mathrm{L}_{03}\right)$ & & & $\begin{array}{l}0.0852 \\
(0.0352)\end{array}$ & $\begin{array}{l}0.2997 \\
(0.0706)\end{array}$ \\
\hline Observations & 19,944 & 21,162 & 1090 & 1253 \\
\hline Year FE & Yes & Yes & No & No \\
\hline Institution $\mathrm{FE}$ & Yes & Yes & No & No \\
\hline Instrument & $\ln \left(\operatorname{Apps}_{\mathrm{it}}\right)$ & $\ln \left(\mathrm{Apps}_{\mathrm{it}}\right)$ & $\begin{array}{l}\ln \left(\operatorname{Apps}_{17}\right)- \\
\ln \left(\text { Apps }_{03}\right)\end{array}$ & $\begin{array}{l}\ln \left(\operatorname{Apps}_{17}\right)- \\
\ln \left(\operatorname{Apps}_{03}\right)\end{array}$ \\
\hline First stage F Stat & 16.9 & 16.1 & 26.2 & 26.8 \\
\hline
\end{tabular}

Notes: The data are taken from IPEDS with the definitions given in the paper. The sample spans the 2002-03 to 2016-17 academic years. Each regression looks at labor supply of the group listed at the top of the column. Standard errors are shown in the parentheses and clustered at the school level. The regressions are weighted by the total faculty head count for the school across the full sample. The dependent variable in columns (1) and (2) is $\ln \left(\mathrm{W}_{\mathrm{it}}\right)$. The dependent variable in (3) and (4) is $\ln \left(\mathrm{W}_{17}\right)-$ $\ln \left(\mathrm{W}_{03}\right)$. The instrument is the lagged level of $\ln$ (Applications) for (1) and (2) and the long difference of lagged applications for (3) and (4) as described in the text.

Second, we consider whether schools' monopsony power is temporary or persistent. To do this, we take the long difference in log wages across our full sample for each school-the 2017 value minus the 2003 value-and regress it on the long difference of the log number of faculty using the long difference in lagged applications as the instrument. We show these results in columns (3) and (4). There is a small positive coefficient on the non-tenure track faculty but a large coefficient for the tenure track. After a long period, the coefficient is actually a bit larger than in the basic regression, suggesting a lasting degree of monopsony power. This may indicate that the nature of that power does not come from the common search frictions and moving costs (which we would think to be temporary) but rather derive from some more permanent source of market power on the part of the schools. 


\section{Correlates of Monopsony Power}

In this section we explore the potential sources of monopsony power that the universities seem to have over their tenure track faculty.

\section{a. Size and Market Share}

Perhaps the most common argument regarding market power is that it derives from concentration. Indeed, the previous literature has often used evidence of a wage-concentration linkage as evidence of monopsony. In Table 6, we compute each school's share of the academic labor market at three levels of aggregation to determine what matters. The first is the school's share of total academic employment (in either tenure track or non-tenure track faculty as applicable) in the school's commuting zone. The second is its share of the academic labor market in its state. The third is its national share, which is really just a measure of the size of the school. ${ }^{11}$

In columns (1) and (2) we interact the quantity term with each of these measures. The results show that the share measure only matters for tenure track faculty and only at the national level. The degree of a college's monopsony power is therefore related to its size, but not any measure of local market share. This is perhaps a sign that tenure track faculty do not seem to operate within local labor markets, or that local concentration is jointly determined by supply and demand factors and as such not monotonically related to market power. The median-sized school (which employs about $0.030 \%$ of tenure track faculty nationwide) faces a residual labor supply elasticity of around 10. At the $75^{\text {th }}$ percentile (employing around $0.064 \%$ of faculty nationwide), the school's elasticity is about 6.1 , and it is 3.2 at the $90^{\text {th }}$ percentile of the size distribution ( $0.153 \%$ of national faculty). In columns (3) and (4) we repeat the regression

11 See Berger et al. (2019) for an examination of the relationship of firm size and monopsony power in the labor market. 
with just the national share/size interaction alone; it shows very similar magnitude coefficients.

Table 6. Inverse Elasticity of Labor Supply: Size and Market Share

\begin{tabular}{ccccc}
\hline $\begin{array}{c}(1) \\
\text { Dep Variable: } \\
\ln \left(\mathrm{W}_{\text {it }}\right)\end{array}$ & $\begin{array}{c}\text { Non- } \\
\text { Tenure } \\
\text { Track }\end{array}$ & $\begin{array}{c}\text { Tenure } \\
\text { Track }\end{array}$ & $\begin{array}{c}(3) \\
\text { Non- } \\
\text { Tenure } \\
\text { Track }\end{array}$ & $\begin{array}{c}(4) \\
\text { Tenure } \\
\text { Track }\end{array}$ \\
\hline $\ln \left(\mathrm{L}_{\text {it }}\right)$ & 0.0402 & 0.1125 & 0.0354 & 0.0501 \\
& $(0.0361)$ & $(0.0742)$ & $(0.0376)$ & $(0.0929)$ \\
$\ln \left(\mathrm{L}_{\text {it }}\right) \times$ National \% & -0.0266 & 1.8052 & -0.0052 & 1.7597 \\
& $(0.1707)$ & $(0.6109)$ & $(0.1336)$ & $(0.5305)$ \\
$\ln \left(\mathrm{L}_{\text {it }}\right) \times$ State \% & 0.0018 & 0.0072 & & \\
& $(0.0018)$ & $(0.0066)$ & & \\
$\ln \left(\mathrm{L}_{\text {it }}\right) \times$ C-Zone \% & -0.0005 & -0.0029 & & \\
& $(0.0004)$ & $(0.0015)$ & & \\
\hline Observations & 19,944 & 21,162 & 19,944 & 21,162 \\
Year FE & Yes & Yes & Yes & Yes \\
Institution FE & Yes & Yes & Yes & Yes \\
Academic Rank & NT & TT & NT & TT \\
First stage F Stat & 14.0 & 6.8 & 28.0 & 12.5 \\
& & & &
\end{tabular}

Notes: The data are taken from IPEDS with the definitions given in the paper. The sample spans the 2002-03 to 2016-17 academic years. Each regression looks at labor supply of the group listed at the top of the column. Standard errors are shown in the parentheses and clustered at the school level. The regressions are weighted by the average total faculty head count for the school across the full sample. The instrument is the lagged level of $\ln$ (Applications) and interactions as relevant in the column. National \% is the average share of the national labor market accounted for by the school in the full sample. State \% is the average share of the state's academic labor market accounted for by the school in the full sample. CZone \% is the same but for the school's commuting zone.

\section{b. School Prestige and Job Differentiation}

Our second potential source of labor market power for a school would be the equivalent of the "brand name" in the product market context. Schools with higher levels of prestige, for example, might have greater monopsony power over their faculty through a differentiation channel. We found no ideal summary statistic for prestige, so we use a few proxies.

First, in Table 7 columns (1) and (2) we use the Carnegie classifications of universities. We allow the monopsony coefficient to vary separately by three categories: R1 schools (doctoral universities with very high research output, of 
which there are around 130), R2 and R3 schools jointly (doctoral universities with high or moderate research output), and all other schools as the excluded group. The results show rather strong monopsony power over tenure track faculty among R1 schools as compared to non-R institutions. The coefficient on the R2-R3 school grouping shows an insignificant but positive coefficient of moderate size. Interestingly, there is some modest evidence of monopsony at the R schools even for non-tenure track faculty (although the combined coefficients are small and not significantly different from zero).

Table 7 Inverse Elasticity of Labor Supply: Institutional Prestige and Market Power

\begin{tabular}{|c|c|c|c|c|c|c|}
\hline $\begin{array}{l}\text { Dep Variable: } \\
\ln \left(\mathrm{W}_{\mathrm{it}}\right)\end{array}$ & $\begin{array}{l}(1) \\
\text { Non- } \\
\text { Tenure } \\
\text { Track }\end{array}$ & $\begin{array}{l}(2) \\
\text { Tenure } \\
\text { Track }\end{array}$ & $\begin{array}{l}\text { (3) } \\
\text { Non- } \\
\text { Tenure } \\
\text { Track }\end{array}$ & $\begin{array}{l}(4) \\
\text { Tenure } \\
\text { Track }\end{array}$ & $\begin{array}{l}\text { (5) } \\
\text { Non- } \\
\text { Tenure } \\
\text { Track }\end{array}$ & $\begin{array}{l}\text { (6) } \\
\text { Tenure } \\
\text { Track }\end{array}$ \\
\hline $\ln \left(\mathrm{L}_{\mathrm{it}}\right)$ & $\begin{array}{l}-0.0162 \\
(0.0354)\end{array}$ & $\begin{array}{l}0.0961 \\
(0.0634)\end{array}$ & $\begin{array}{l}0.0146 \\
(0.0353)\end{array}$ & $\begin{array}{l}0.1074 \\
(0.0714)\end{array}$ & $\begin{array}{l}0.0010 \\
(0.0646)\end{array}$ & $\begin{array}{l}-0.1246 \\
(0.0636)\end{array}$ \\
\hline $\ln \left(L_{\mathrm{it}}\right) \times \mathrm{R} 1$ & $\begin{array}{l}0.0788 \\
(0.0301)\end{array}$ & $\begin{array}{l}0.6857 \\
(0.1093)\end{array}$ & & & & \\
\hline $\ln \left(L_{i t}\right) \times R 2 / R 3$ & $\begin{array}{l}0.0930 \\
(0.0285)\end{array}$ & $\begin{array}{l}0.1848 \\
(0.1154)\end{array}$ & & & & \\
\hline $\begin{array}{l}\ln \left(L_{i t}\right) \times \mathrm{SAT} \\
\mathrm{Q} 4\end{array}$ & & & $\begin{array}{l}0.0502 \\
(0.0297)\end{array}$ & $\begin{array}{l}0.5181 \\
(0.0920)\end{array}$ & & \\
\hline $\begin{array}{l}\ln \left(L_{\text {it }}\right) \times \text { Salary } \\
\text { Pctile }(1-100)\end{array}$ & & & & & $\begin{array}{l}0.0007 \\
(0.0007)\end{array}$ & $\begin{array}{l}0.0075 \\
(0.0015)\end{array}$ \\
\hline Observations & 19,944 & 21,162 & 18,293 & 19,766 & 17,402 & 19,104 \\
\hline Year FE & Yes & Yes & Yes & Yes & Yes & Yes \\
\hline Institution FE & Yes & Yes & Yes & Yes & Yes & Yes \\
\hline Instrument & $\ln \left(\mathrm{Apps}_{\mathrm{t}-1}\right)$ & $\ln \left(\mathrm{Apps}_{\mathrm{t}-1}\right)$ & $\ln \left(\operatorname{Apps}_{\mathrm{t}-1}\right)$ & $\ln \left(\mathrm{Apps}_{\mathrm{t}-1}\right)$ & $\ln \left(\mathrm{Apps}_{\mathrm{t}-1}\right)$ & $\ln \left(\mathrm{Apps}_{\mathrm{t}-1}\right)$ \\
\hline F-Stats & 15.6 & 15.6 & 14.1 & 19.1 & 28.0 & 12.5 \\
\hline $\begin{array}{l}\text { Notes: The } \\
2002-03 \text { to } 201 \\
\text { of the column. } \\
\text { regressions are } \\
\text { instrument is } t \\
\text { R1/R2/R3 clas } \\
\text { dummy variabl } \\
\text { Salary Pctile is } \\
\text { first year of the }\end{array}$ & $\begin{array}{l}\text { tia are take } \\
17 \text { academi } \\
\text { ndard erro } \\
\text { ighted by t } \\
\text { iagged level } \\
\text { cations refe } \\
\text { r whether } \\
\text { ppercentile } \\
\text { mple. }\end{array}$ & $\begin{array}{l}\text { Om IPEDS } \\
\text { ars. Each r } \\
\text { e shown it } \\
\text { verage tota } \\
\text { napplicati } \\
\text { the Carne } \\
\text { chool's av } \\
\text { king (from }\end{array}$ & $\begin{array}{l}\text { parenthese } \\
\text { llty head co } \\
\text { and interac } \\
\text { assification } \\
\text { SAT score } \\
\text { ST sof }\end{array}$ & $\begin{array}{l}\text { or the sch } \\
\text { as relevan } \\
\text { esearch ur } \\
\text { the top qua } \\
\text { ty salary }\end{array}$ & $\begin{array}{l}\text { r. The samp } \\
\text { e group liste } \\
\text { le school lev } \\
\text { cross the fu } \\
\text { he column. } \\
\text { sities. SAT } \\
\text { of schools } \\
\text { or full profe }\end{array}$ & $\begin{array}{l}\text { spans the } \\
\text { at the top } \\
\text { The } \\
\text { ample. The } \\
\text { le } \\
\text { is a } \\
\text { PEDS. } \\
\text { ors in the }\end{array}$ \\
\hline
\end{tabular}


Next, in columns (3) and (4) we allow the coefficient to vary for schools in the top quartile of average SAT score of the students. ${ }^{12}$ Again, there is no significant relationship between the wage and hiring for non-tenure track faculty at any schools. But there is strong evidence of monopsony power over the tenure track faculty at the schools with the highest student test scores. Indeed, monopsony power appears to be concentrated among these 400 or so schools; lower test score schools exhibit no significant evidence of monopsony power even over their tenure track faculty.

In columns (5) and (6) we rank schools prestige by the relative salary of full professors in the first year in the sample. The schools with the lowest initial pay for full professors (nationally) have a percentile ranking of 1 and the highest have rankings of 100 . We find again that a proxy for prestige is associated with greater monopsony power.

\section{Monopsony and the Rise of Non-Tenure track Faculty}

The evidence indicates that schools have significant and durable monopsony power over their tenure track faculty, and especially so at larger and more prestigious (by several measures) schools. In contrast, they are pricetakers for non-tenure track faculty.

That asymmetry raises an interesting implication regarding substitution toward adjunct faculty as universities increase their scale.

There has been a well-documented rise in the share of non-tenure track faculty at American universities during our sample (see American Association of University Professors, 2017). Our data document the same thing. Figure 2 shows the year dummies from a regression of the share of non-tenure track faculty among total full-time faculty on school and year dummies. The mean share in the sample started at around $12 \%$ in 2003 . The figure documents a

12 Unsurprisingly, using ACT scores instead of SAT scores did not change the results. 
roughly $50 \%$ increase in (in our case full-time) non-tenure track faculty share over the sample. ${ }^{13}$

The standard discussion of this rise centers on the bargaining power of universities and their ability to exploit adjunct faculty. Indeed, this has been the rallying point of efforts at several universities of the adjunct faculty to unionize in order to improve their bargaining power.

Our results raise the important point that pay can be low for adjunct faculty without that indicating universities having market power in the traditional monopsony sense. In other words, our results indicate that low equilibrium wages for adjunct faculty may arise from the aggregate labor supply curve of adjunct faculty is shifted out enough relative to demand to result in a low market wage. It is not because individual universities are holding back on hiring more adjuncts to avoid raising their wages.

In addition, we know that there has been a dramatic expansion of both enrollments and applications to schools over this time period (resulting from demographic changes, a rise in international demand, and increasing returns to education, among other reasons). We can see this in our data. Figure 3 plots the year dummies from regressions of log applications and log enrollments on institution and year fixed effects. If tenure track and non-tenure track faculty are substitutes, and schools have monopsony power over one and the other, we would expect expanding universities to shift their labor mix toward the competitive input, as the monopsonistic input becomes increasingly expensive.

The rate of this shift depends on the slope of the residual labor supply curve for tenure track faulty as well as the production function for the school. The latter parameterizes the output elasticity of each type of labor and the

\footnotetext{
${ }^{13}$ We found the same thing plotting year dummies from a regression including part-time faculty, as well. This is fully in keeping with our argument earlier in the paper that the share of full-time adjunct faculty has remained constant even as the share of adjunct faculty has increased substantially.
} 
degree of substitutability between them. We do not have a straightforward way to estimate the production function directly. However, we can look at indirect evidence to get a sense of how much of the rise of non-tenure track faculty might be tied to universities' monopsony power over tenure track faculty.

First, we take the first stage of our IV results from Table 3 above, where we estimated a relationship between the number of applications to a school and the number of faculty of each type. We can use this to compute a projected impact of the 75-log-point increase in applications over the sample on the quantity of tenure track and non-tenure track faculty. An important flaw in this calculation, of course, is that such estimates are premised on there not being an aggregate labor supply elasticity effect. This calculation predicts how the aggregate shares of each type of faculty would change if all schools expanded hiring simultaneously, but does so using relationships from variation in how individual schools changed hiring when their applications changed. If the aggregate labor supply elasticity of tenure track and non-tenure track differs, extrapolating the cross section in this way would be mistaken. The direction of the bias could go either way.

That caveat noted, the first stage results from Table 3 imply that a 75-logpoint increase in applications would correspond to an increase in non-tenure track faculty of $18 \log$ points and of tenure track faculty of $6 \log$ points. This implied increase in the share of non-tenure track faculty accounts for about $20 \%$ of the total increase observed in the data. In other words, the substitution toward adjuncts would have been about $20 \%$ smaller if colleges faced flat residual labor supply curves for tenure track faculty.

The second bit of suggestive evidence that tenure track monopsony is tied to the rise of non-tenure track faculty is to compare the rise across schools that the results suggest have more or less monopsony power. We ought to see that larger and more prestigious schools should have substituted more heavily toward non-tenure track faculty. 
Figures 4, 5, and 6 show the year dummies from regressions of the share of faculty at a school that is non-tenure track on school and year dummies. Each figure compares these estimates for sets of schools that we found above exhibit higher and lower monopsony power. In each case, we see a much larger increase in the share of non-tenure track faculty at schools with more estimated labor market power. Specifically, larger schools (Figure 4), higher SAT score schools (Figure 5), and higher initial full professor salary schools (Figure 6) each saw larger growth in their use of non-tenure track faculty. This suggests that monopsony may be playing an important role in recent years' shift away from tenure track faculty.

\section{Conclusion}

We have developed and applied a method for testing for the presence and measuring the amount of monopsony power of colleges and universities in the US. We use direct estimation of the residual supply curve facing each institution using demand instruments. The results document that schools have no significant monopsony power over adjunct faculty, but do hold substantial and lasting monopsony power over tenure track faculty.

The monopsony power is monotonic in academic rank but does not seem to differ across men and women faculty. It has been rising over our sample. Market power is concentrated at larger schools as well as at more prestigious schools, as measured by Carnegie classifications, student test scores, and other measures.

The presence of market power over the tenure track part of the faculty gives universities an incentive to shift to non-tenure track labor when demand rises (in order to prevent driving up tenure track wages). By that means, monopsony has likely played some role in the rise of adjunct faculty in recent years. Consistent with this, we find that schools with larger estimated market power have shifted more intensively to adjunct faculty than those with less. 
While we do not have direct evidence on whether schools are fully exploiting their market power by the degree implied by cost-minimization of a monopsonistic employer, the degree of market power they have over their tenure track faculty implies they could sustain a rather substantial wedge between wages and marginal product of labor. 


\section{Bibliography}

Abel, Will, Silvana Tenreyro, and Gregory Thwaites. 2018. "Monopsony in the UK." CEPR Discussion Paper 13265.

Adamache, Killard W., and Frank A. Sloan. 1982. "Unions and Hospitals: Some Unresolved Issues.” Journal of Health Economics 1(1): 81-108.

American Association of University Professors. 2017. "Trends in the Academic Labor Force 1975-2015." Website accessed 6/18/2019 $<$ https://www.aaup.org/sites/default/files/Academic_Labor_Force_Trends_197 5-2015.pdf $>$

Ashenfelter, Orley C., Henry Farber, and Michael R. Ransom. 2010. "Modern Models of Monopsony in Labor Markets: A Brief Survey." Journal of Labor Economics, 28(2): 203-10.

Azar, José A., Ioana Marinescu, Marshall I. Steinbaum, and Bledi Taska. 2019. "Concentration in US Labor Markets: Evidence From Online Vacancy Data.” NBER Working Paper No. 24395.

Baker, Jonathan B. and Timothy F. Bresnahan. 1988. "Estimating the Residual Demand Curve Facing a Single Firm," International Journal of Industrial Organization, 6(3): 283-300.

Barth, Erling and Harald Dale-Olsen. 2009. "Monopsonistic Discrimination, Worker Turnover and the Gender Wage Gap." Labour Economics, 16(5): 589-97.

Berger, David, Kyle Herkenhoff and Simon Mongey, 2019. "Labor Market Power." NBER Working Paper 25719, March.

Boal, William M. 1995. "Testing for Employer Monopsony in Turn-of-theCentury Coal Mining.” RAND Journal of Economics, 26(3): 519-36.

Boal, William M. and Michael R. Ransom. 1997. "Monopsony in the Labor Market." Journal of Economic Literature, 35(1): 86-112.

Bodenheimer, Rebecca. 2018. "University Teachers Are Exploited, Too." May 9, https://www.cnn.com/2018/05/08/opinions/teachers-pay-adjunctssouthern-illinois-bodenheimer-opinion/index.html, accessed 6/21/2019.

Brown, Robert W. 1993. "An Estimate of the Rent Generated by a Premium College Football Player." Economic Inquiry, 31(4): 671-84. 
Card, David E. and Alan B. Krueger. 1995. Myth and Measurement: The New Economics of the Minimum Wage. Princeton NJ: Princeton University Press.

Card, David E., and Alan B. Krueger. 2000. "Minimum Wages and Employment: A Case Study of the Fast-Food Industry in New Jersey and Pennsylvania: Reply." American Economic Review, 90(5): 1397-1420.

Card, David E., Ana Rute Cardoso, Joerg Heining, and Patrick Kline. 2018. "Firms and Labor Market Inequality: Evidence and Some Theory." Journal of Labor Economics, 36(S1): S13-S70.

Card, David, Alexandre Mas, Enrico Moretti, and Emmanuel Saez. 2012. "Inequality at Work: The Effect of Peer Salaries on Job Satisfaction." American Economic Review, 102(6): 2981-3003.

Childress, Herb. 2019. The Adjunct Underclass. University of Chicago Press. Chicago.

Chronicle of Higher Education. 2019. "How to Fix the Adjunct Crisis: Four Views from the Tenure Track." https://www.chronicle.com/article/How-to-Fixthe-Adjunct-Crisis/243535, accessed 6/21/2019.

Dal Bó, Ernesto, Frederico Finan, and Martín A. Rossi. 2013.

"Strengthening State Capabilities: The Role of Financial Incentives in the Call to Public Service." Quarterly Journal of Economics, 128(3): 1169-1218.

Dube, Arindrajit, Jeff Jacobs, Suresh Naidu, and Siddharth Suri. Forthcoming. "Monopsony in Online Labor Markets." American Economic Review: Insights.

Dube, Arindrajit, Suresh Naidu, and Michael Reich. 2007. "The Economic Effects of a Citywide Minimum Wage.” ILR Review, 60(4): 522-43.

Falch, Torberg. 2010. "The Elasticity of Labor Supply at the Establishment Level." Journal of Labor Economics, 28(2): 237-266.

Fox, Jeremy T. 2010. "Estimating the Employer Switching Costs and Wage Responses of Forward-Looking Engineers." Journal of Labor Economics. 28(2): 357-412.

Fishback, Price V. 1992. "The Economics of Company Housing: Historical Perspectives from the Coal Fields." Journal of Law, Economics, and Organization, 8(2): 346- 65. 
Fredrickson, Caroline. 2015. "There Is No Excuse for How Universities Treat Adjuncts." September 15, The Atlantic, https://www.theatlantic.com/business/archive/2015/09/higher-educationcollege-adjunct-professor-salary/404461/, accessed 6/21/2019.

Ginder, Scott A., Janice E. Kelly-Reid, Farrah B. Mann. 2018. “2017-18 Integrated Postsecondary Education Data System (IPEDS) Methodology Report.” July, National Center for Education Statistics, https://nces.ed.gov/pubs2018/2018195.pdf, accessed 6/18/2019.

Ginther, Donna K. and Kathy J. Hayes. 1999. "Gender Differences in Salary and Promotion in the Humanities." American Economic Review Papers and Proceedings, 89(2): 397-402.

Hallock, Kevin F. 1995. "Seniority and Monopsony in the Academic Labor Market." American Economic Review, 85(3): 654-657.

Hirsch, Barry T. and Edward Schumacher. 1995. "Monopsony Power and Relative Wages in the Labor Market for Nurses." Journal of Health Economics, 14(4): 443-76.

Hirsch, Boris, Thorsten Schank, and Claus Schnabel. 2010. "Differences in Labor Supply to Monopsonistic Firms and the Gender Pay Gap: An Empirical Analysis Using Linked Employer-Employee Data from Germany." Journal of Labor Economics, 28(2): 291-330.

Hoeller, Keith. 2014. "The Wal-Martization of Higher Education: How Young Professors are Getting Screwed." February 16, https://www.salon.com/2014/02/16/the_wal_mart_ization_of_higher_educatio n_how_young_professors_are_getting_screwed/, accessed 6/21/2019.

Hoffman, Emily P. 1976. "Faculty Salaries: Is There Discrimination by Sex, Race, and Discipline? Additional Evidence." American Economic Review, 66(1): 196-98.

Isen, Adam. 2013. "Dying to Know: Are Workers Paid Their Marginal Product?" University of Pennsylvania Wharton School of Business Working Paper.

Kahn, Lawrence M. 2000. "The Sports Business as a Labor Market Laboratory." Journal of Economic Perspectives, 14(3): 75-94.

Karatzas, George. 2009. "On the Origin and the Literal Meaning of Monopsony: A Note.” International Review of Economics, 56(4): 425-30. 
Kline, Patrick, Neviana Petkova, Heidi Williams, and Owen Zidar. 2017. "Who Profits from Patents? Rent-Sharing at Innovative Firms." Institute for Research on Labor and Employment Working Paper No. 107-17.

Lamadon, Thibault, Magne Mogstad, and Bradley Setzler. 2019. "Imperfect Competition, Compensating Differentials, and Rent Sharing in the U.S. Labor Market." Becker Friedman Institute Working Paper 2019-84.

Luizer, James and Robert Thornton. 1986. "Concentration in the Labor Market for Public School Teachers." Industrial and Labor Relations Review, 39(4): 573-84.

Manning, Alan. 1996. "The Equal Pay Act as an Experiment to Test Theories of the Labour Market." Economica, 63(250): 191-212.

Manning, Alan. 2003. Monopsony in Motion. Princeton, NJ: Princeton University Press.

Manning, Alan. 2011. "Imperfect Competition in the Labor Market." Prepared for Handbook of Labor Economics, vol. 4B. Elsevier: Amsterdam. 9731041

Mas, Alexandre and Amanda Pallais. 2017. "Valuing Alternative Work Arrangements." American Economic Review, 107(12): 3722-59.

Matsudaira, Jordan D. 2014. "Monopsony in the Low-Wage Labor Market? Evidence from Minimum Nurse Staffing Regulations." Review of Economics and Statistics, 96(1): 92-102.

Monks, James and Michael Robinson. 2000. "Gender and Racial Earnings Differentials in Academic Labor Markets." Economic Inquiry, 384): 662-71.

Monks, James and Michael Robinson. 2001. "The Returns to Seniority in Academic Labor Markets," Journal of Labor Research, 22(2): 415-27.

Naidu, Suresh. 2010. "Recruitment Restrictions and Labor Markets: Evidence from the Postbellum U.S. South." Journal of Labor Economics, 28(2): 413-45.

Naidu, Suresh, Yaw Nyarko, and Shing-Yi Wang. 2016. "Monopsony in Migrant Labor Markets: Evidence from the United Arab Emirates." Journal of Political Economy, 124(6): 1735-92.

Naidu, Suresh, Eric Posner, and E. Glen Weyl. 2018. “Antitrust Remedies for Market Power." Harvard Law Review, 132(2). 
Neumark, David and William Wascher. 2000. "Minimum Wages and Employment: A Case Study of the Fast-Food Industry in New Jersey and Pennsylvania: Comment." American Economic Review, 90(5): 1362-96.

O’Shaughnessy, Lynn. 2012. "Do Colleges Exploit Their Professors?" Moneywatch, November 27, 2012, https://www.cbsnews.com/news/docolleges-exploit-their-professors, accessed 6/21/2019.

Parsons, Donald O. 1972. "Specific Human Capital: An Application to Quit Rates and Layoff Rates.” Journal of Political Economy, 80(6): 1120-43.

Pencavel, John. 1972. "Wages, Specific Training, and Labor Turnover in U.S. Manufacturing Industries." International Economic Review, 13(1): 53-64.

Pigou, Arthur C. 1924. The Economics of Welfare, 2nd Edition. London: Macmillan.

Prager, Elena and Matthew Schmitt. 2019. "Employer Consolidation and Wages: Evidence from Hospitals." Washington Center for Equitable Growth Working Paper.

Ransom, Michael R. 1993. "Seniority and Monopsony in the Academic Labor Market." American Economic Review, 83(1): 221-231.

Ransom, Michael R. and Ronald Oaxaca. 2010. "Sex Differences in Pay in a 'New Monopsony' Model of the Labor Market." Journal of Labor Economics, 28(2): 267-89.

Ransom, Michael R, and David P. Sims. 2010. "Estimating the Firm's Labor Supply Curve in a 'New Monopsony' Framework: School Teachers in Missouri." Journal of Labor Economics, 28(2): 331-5.

Robinson, Joan. 1969. The Economics of Imperfect Competition. 2nd ed. London: Macmillan.

Scully, Gerald W. 1974. "Pay and Performance in Major League Baseball." American Economic Review, 64(6): 915-30.

Somppi, Ken. 1985. "Salary vs. Marginal Revenue Product under Monopsony and Competition: The Case of Professional Basketball." Atlantic Economic Journal, 13(3): 50-59. 
Staiger, Douglas, Joanne Spetz, and Ciaran Phibbs. 2010. "Is There Monopsony in the Labor Market? Evidence from a Natural Experiment." Journal of Labor Economics, 28(2): 211-36.

Sullivan, Daniel. 1989. "Monopsony Power in the Market for Nurses." Journal of Law and Economics, 32(2): S135-78.

Tuckman, Howard and David Katz. 1981. "Estimation of Relative Elasticities of Substitution and Relative Compensation for Part-Time Faculty." Economics of Education Review, 1(3): 359-66.

Tyler, Elanor. 2018. "Justice Department Is Going After 'No-Poach' Agreements.” Bloomberg BNA (Jan. 19, 2018), https://www.bna.com/justicedept-going-n73014474358/.

U.S. Department of Justice and Federal Trade Commission. 2016. Antitrust Guidance for Human Resource Professionals.

U.S. Department of Justice. 2019. "Statement of the Interest of the United States of America." Seaman vs Duke University et al. Civil No. 1:15-cv-462 Judge Catherine C. Eagles <https://www.justice.gov/atr/casedocument/file/1141756/download)>, accessed 6/20/2019.

U.S. Department of the Treasury, Office of Econ. Policy. 2016. Non-Compete Contracts: Economic Effects and Policy Implications.

Zimbalist, Andrew. 1992. "Salaries and Performance: Beyond the Scully Model." In Diamonds Are Forever: The Business of Baseball, edited by Paul M. Sommers, 109-133. Washington DC: Brookings Institution. 
Figure 1:

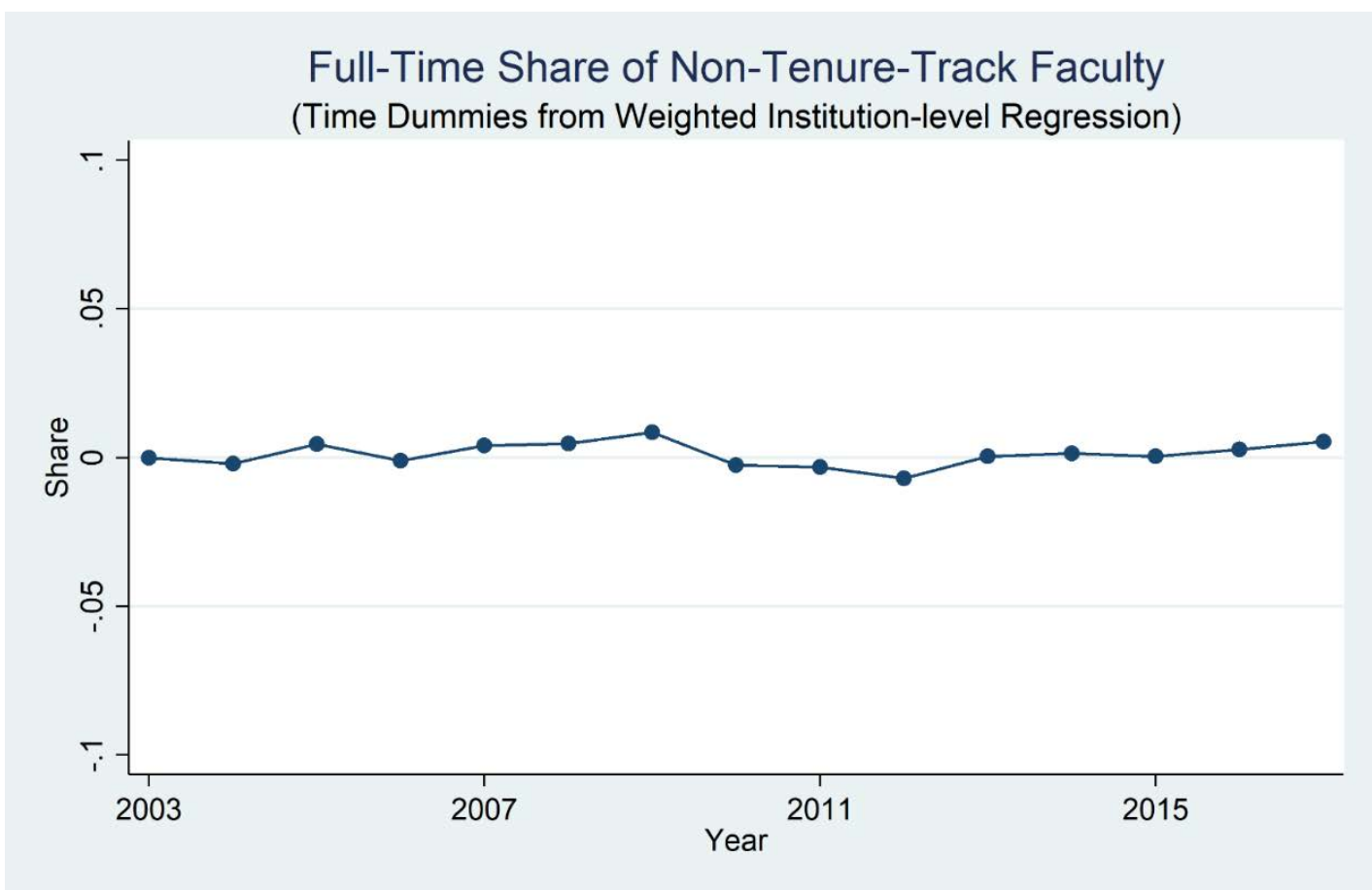

Figure 2:

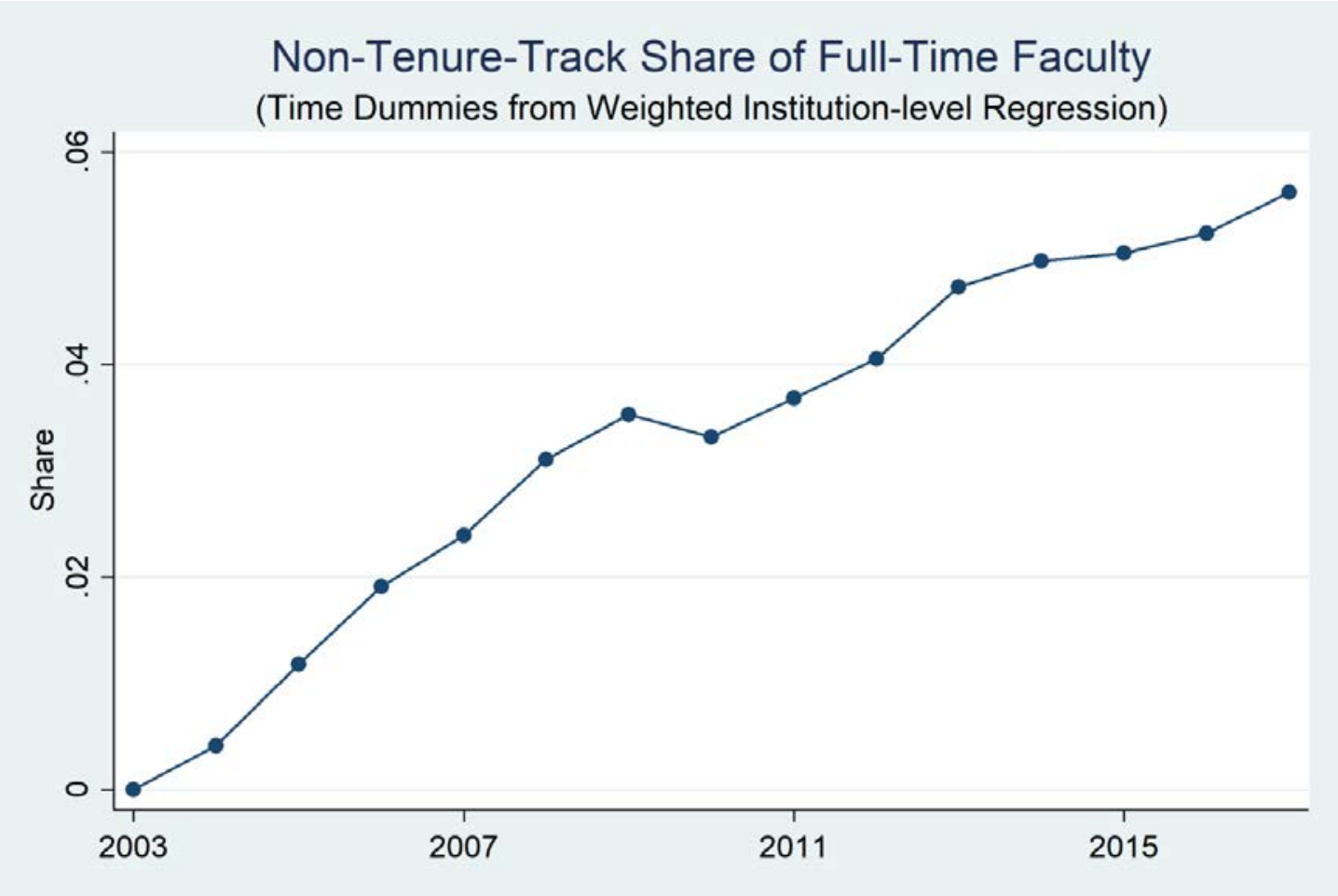


Figure 3:

\section{Application and Enrollment Trends Over Time}

(Time Dummies from Weighted Institution-level Regression)

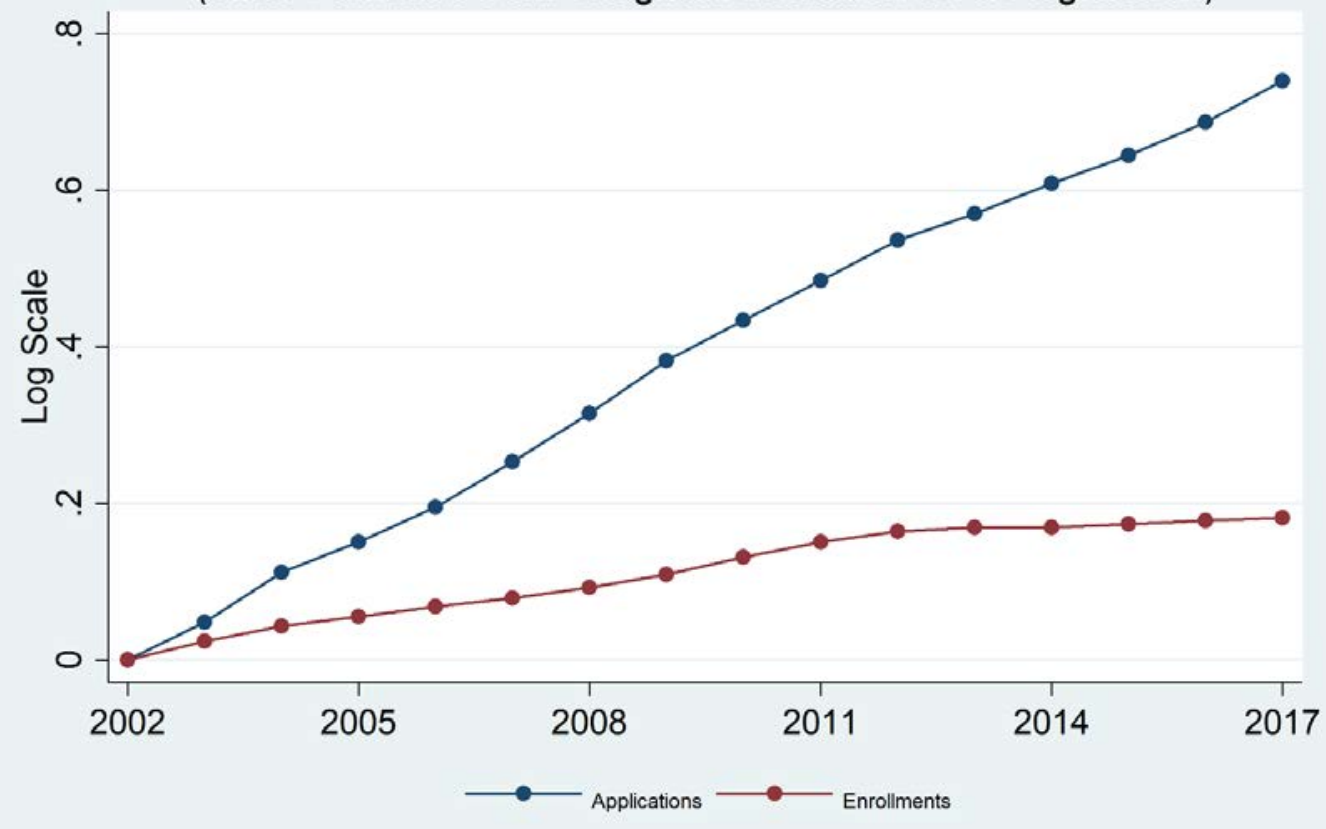

Figure 4:

Non-Tenure-Track Share of Full-Time Faculty

By National Concentration Quartile

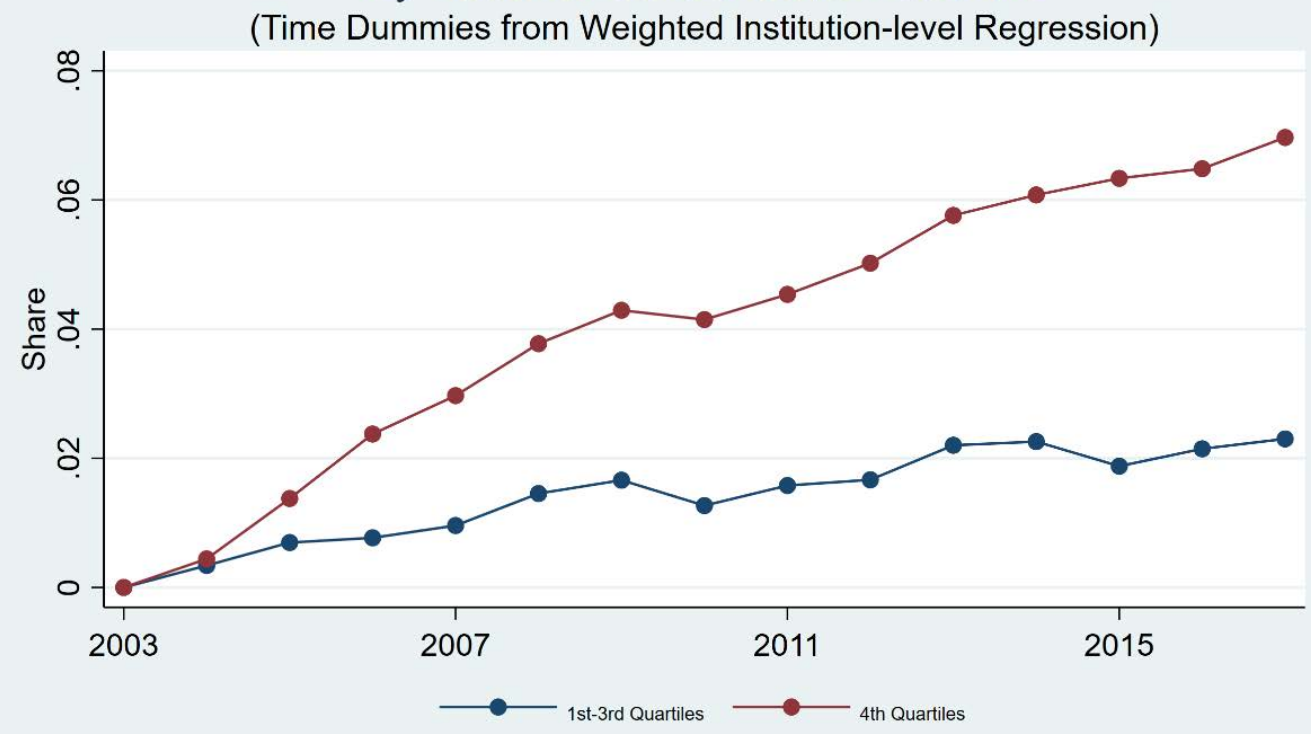




\section{Figure 5:}

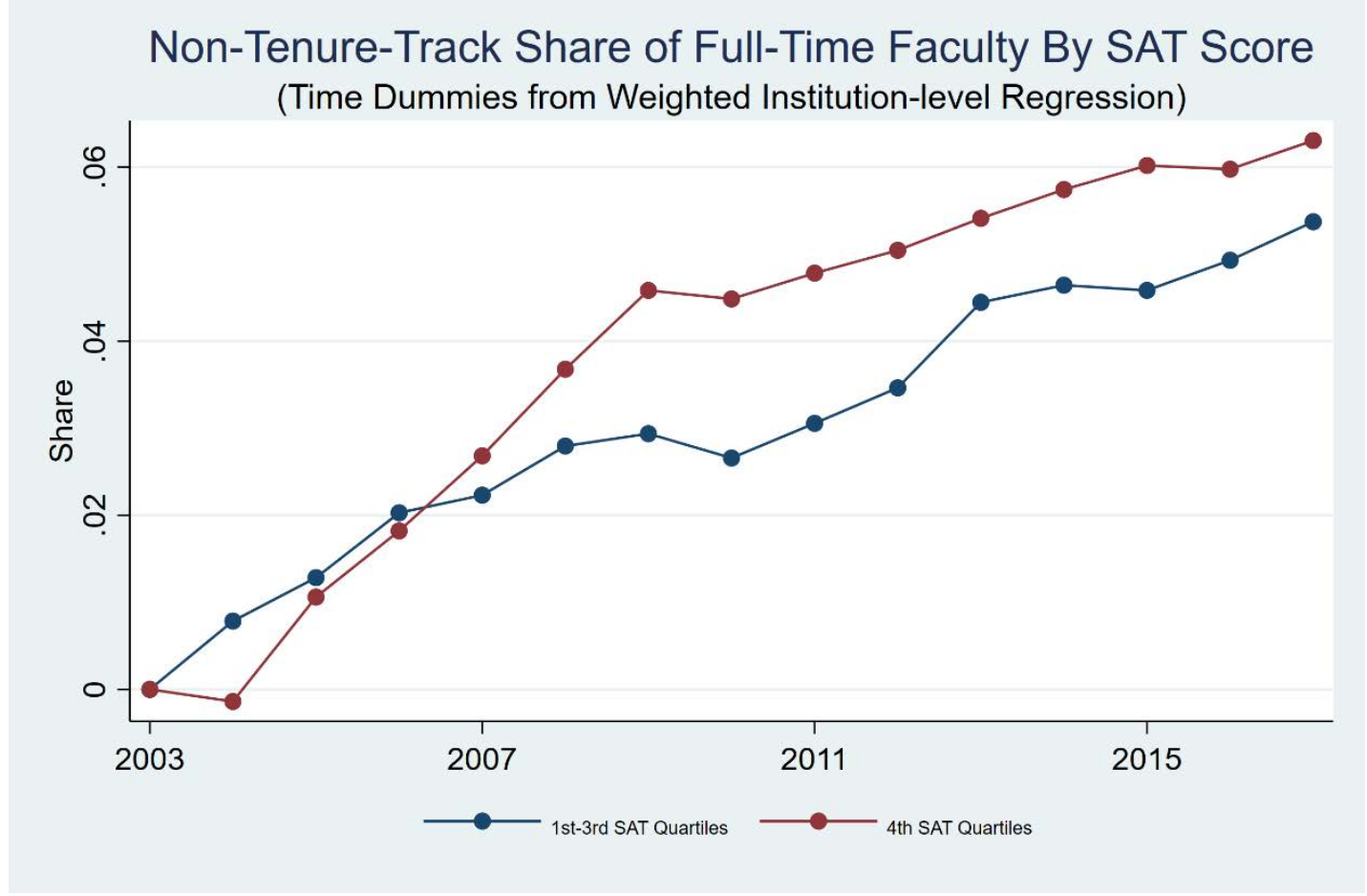

Figure 6:

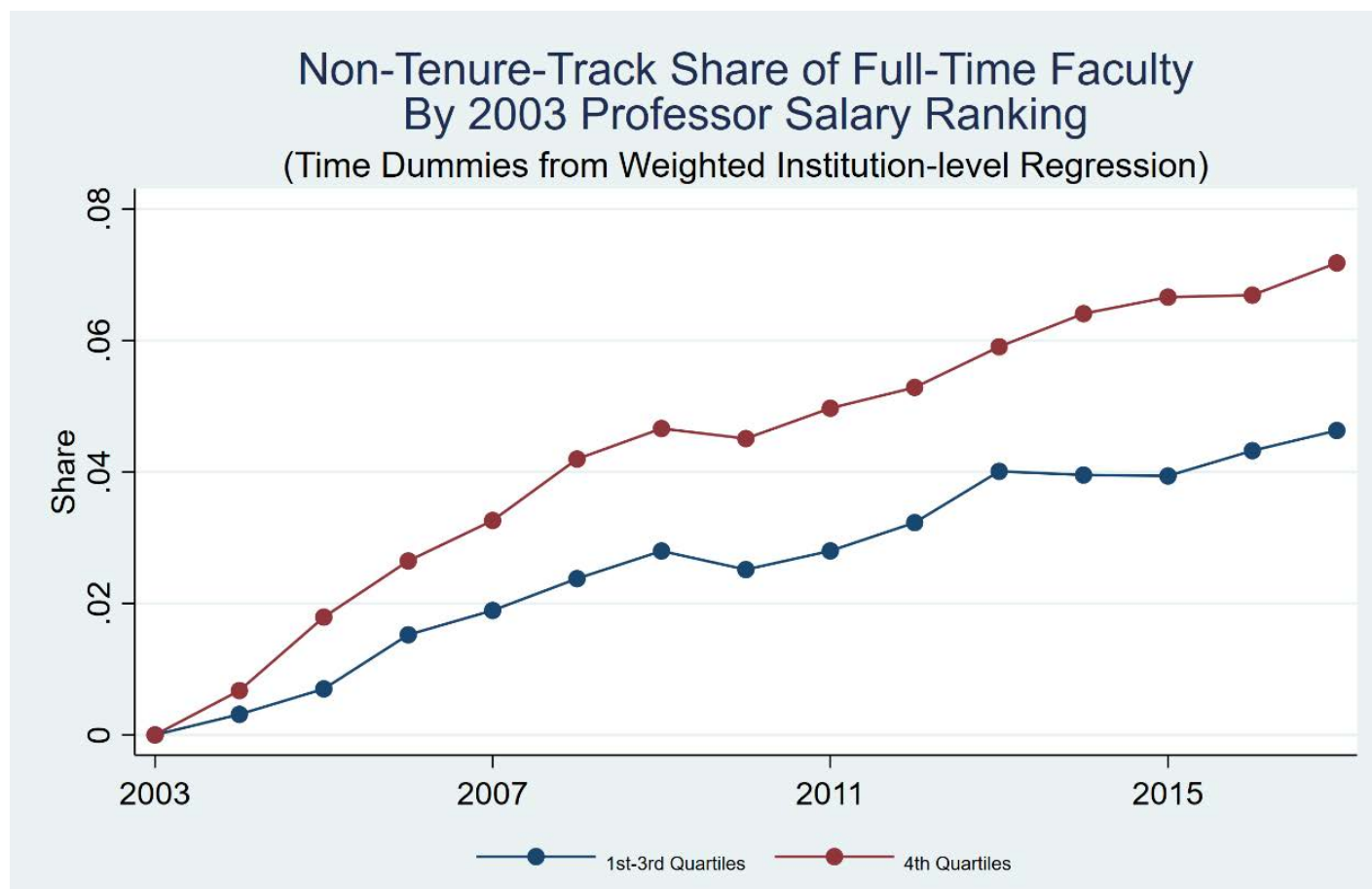

